\title{
Perspective on the control of invasive mesquite trees and possible alternative uses
}

\author{
Seth W Ellsworth ${ }^{(1)}$, \\ Philip G Crandall ${ }^{(1-2)}$, \\ Jody M Lingbeck ${ }^{(2)}$, \\ Corliss A O’Bryan (2)
}

\begin{abstract}
Mesquite trees continue to invade forests and range lands in many countries across the world. The cost to remove these trees is staggering. In Texas, landowners spent $\$ 25$ million over a 10 -year period to clear 300.000 ha of mesquite trees, a fraction of the 22 million ha of Texas land affected by this invasion. Estimates are that the mesquite continues to negatively impact one to two percent of additional land in selected counties each year in Texas. However, the problem is not unique to Texas, but rather to the 44 species of mesquite trees, belonging to the genus Prosopis found in the pea family (Fabaceae), introduced across the southern United States, South Asia, Africa, the Middle East, South America, and the Caribbean. In response, researchers are searching for economically viable uses for harvested trees and seeds to provide an alternative to the high cost of removal. If viable uses for harvested mesquite trees and seeds are found, then sustained pressure will limit and ultimately reduce the negative impact from these invasive trees. One key factor to controlling this invasive species is to find economically and environmentally sustainable uses to help pay the costs of removal or perhaps make removal less necessary. Traditional uses of mesquite are as a building material, as a source of food for both animals and humans and as wood for charcoal. Emerging uses of mesquite are new applications as a biofuel and as a bio-filter medium for water. Moreover, forestry land management of mesquite has adapted to include the tree as a component of hunting lands. New control methodologies and technologies are based on an increased understanding of mesquite growth patterns, using recommended practices that reduce control and eradication costs while improving the efficiency of land management. Previous land management practices have proven that excessive application of herbicides, physical removal of mesquite trees, or human-induced brush fires, if not carefully planned, only worsen mesquite infestations. The growing problem of mesquite land management provides an opportunity for continued research into novel ways to utilize mesquite biomass, of both wood and seed pods.
\end{abstract}

Keywords: Mesquite, Land Management, Prosopis spp., Biofuel

of the southern United States, South Asia, Africa, the Middle East, South America, and the Caribbean (Burkart 1976, Rogers 2000). The origin of the Prosopis genus is traced to Argentina, where 34 of the 44 species are native to Argentina's northern region (Rogers 2000). It stands to reason that much of the research studying the biology of the Prosopis species are centered in Argentina at the Universidad Católica de Santiago del Estero (Ewens et al. 2012).

Texas, the second largest state in the United States of America (USA), has a land mass of nearly 70 million ha, 22 million ha of which have been reduced in value due to mesquite invasion. Mesquite's rapid expansion started when early cattle ranchers in Texas initially used mesquite seed pods as feed to supplement cattle diets during long cattle drives to Northern markets. While passing through an animal digestive tract, the mesquite seeds are scarified and then excreted in manure, which is a perfect growing medium. These processes contributed to mesquite's rapid expansion across much of Texas' rangeland (DeLoach 1984). Over the 10-year period from Fiscal Year 2000 to Fiscal Year 2010 the Texas State Soil and Water Conservation Board (TSSWCB) spent almost 50 million US \$ treating approximately 300,000 ha with herbicides and the mechanical removal of this invasive species. The goal of the TSSWCB efforts were to enhance water availability through selective brush control (TSSWCB 2010). Mesquite trees have continued to invade additional land, increasing their coverage by about two percent annually in certain Texas counties, based on long term studies conducted since 1976, which observed the changes in honey mesquite (Prosopis glandulosa) canopy cover during a 20-year period (Ansley et al. 2001). Thus, mesquite continues to increase in land coverage in spite of huge expenditures on control measures. The immense density of the mesquite species invasion in the USA remains the highest in Texas (Fig. 1). In addition to diminishing the value of Texas grazing lands, mesquite trees' expansion in 


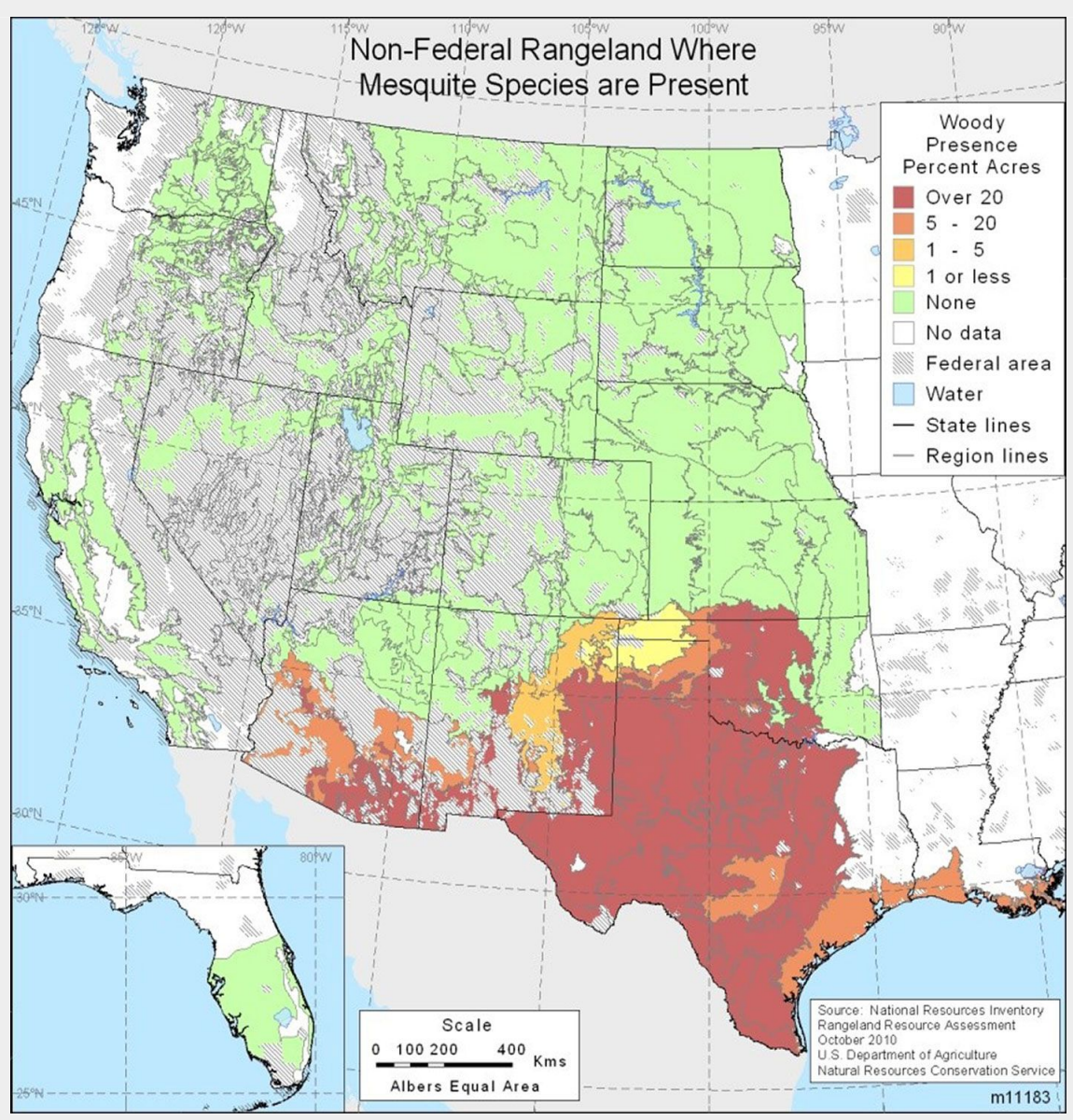

Fig. 1 - Adapted map of non-federal rangeland where mesquite species are present (FSIS-USDA 2016).

southeastern New Mexico negatively impacted the breeding of lesser prairiechicken (Tympanuchus pallidicinctus), a species of conservation concern (Boggie et al. 2017).

Mesquite trees are legumes and like many legumes have the ability to enrich the soil around their roots by fixing atmospheric nitrogen symbiotically with particular soil bacteria. This ability to enrich soil initially made them attractive to combat desertification, especially in arid African countries (Geesing et al. 2000, Shackleton et al. 2014). Members of the genus Prosopis are, in some aspects, the ideal candidate to combat desertification across wide expanses of the world because mesquite trees can grow in highly alkaline soils, tolerating a pH up to 9.5 to 10.0 and a soluble salt content between $0.54 \%$ and $1.0 \%$ (Rogers 2000). However, in many parts of the world their uncontrolled spread has significantly decreased the value of the rangeland they were meant to improve and enrich. Unfortunately, mesquite trees can quickly become a biological nightmare as happened in Sudan. Sudan once heralded the mesquite as the "miracle tree" that could help stave off the threat of desertification and increase the biodiversity in Sudan's deserts (Babiker 2006). However, mesquite now completely dominates portions of Sudan's once tillable farm land and has been reclassified as a noxious weed as part of their government-sponsored mesquite eradication program (Rogers 2000, Shackleton et al. 2014).

Prosopis juliflora trees have an extensive root system which have been found to penetrate as deep as $53 \mathrm{~m}$ (Jackson et al. 1996), and the P. glandulosa's root depth has been recorded down to $50 \mathrm{~m}$ (Canadell et al. 1996). These deep root systems are combined with a surface root system that may cover up to $15 \mathrm{~m}$ in circumference, together making them a fierce competitor for soil moisture. Mesquite trees can become quite large with the honey mesquite known to grow to $7.6 \mathrm{~m}$ in height with its main support trunk as large as $0.6 \mathrm{~m}$ in diameter. Normally, a mesquite tree has a single main trunk with minimal ancillary branching; however, damage to the upper portion of the tree from either animal foraging or human eradication efforts, causes multiple re-sprouting of the stems which can exacerbate the problems of mesquite invasion. During a drought, vegetative growth stops, but will resume quickly after a period of rainfall. Flowering occurs as leaves develop and will later form the seed pods of the mesquite tree (Ansley et al. 1997).

As legumes, mesquite trees have a symbiotic relationship with bacteria of the genus Rhizobium in their root nodules, which is where atmospheric nitrogen fixation occurs in the soil. Increased understanding of biological nitrogen fixation has occurred by measuring nitrogen-fixation in Prosopis glandulosa. Soper et al. (2015) took samples from the entire nitrogen uptake pathway including soil solution, xylem sap, and foliage; a large variation of about $70 \%$ was found in nitrogen fixation values from each of these sampling locations. The quantity of nitrogen fixation is inversely related to the diameter of the mesquite tree (López Villagra \& Felker 1997). Thus, a younger mesquite tree will fix more nitrogen than a larger, more mature tree. This characteristic probably enables newly established mesquite trees to colonize even the lowest fertility soils. Mature trees appear to obtain most of their nitrogen needs from the soil (Geesing et al. 2000). This fixation of nitrogen may be related to the fact that certain species of mesquite can grow in saline soils (soils with high levels of salt) with salt levels 10 times greater than the maximum salt levels tolerated by common commercial legumes, such as soybeans (Velarde et al. 2003).

Mesquite and some species of the genus Acacia, another nitrogen-fixing tree, have been estimated to be able to fix $30-40 \mathrm{~kg} \mathrm{~N}$ ha $^{-1}$ year $^{-1}$ (Felker et al. 2013). Leaf and branch litter that fall from the mesquite trees was also shown to increase the resorption of nitrogen and phosphorus, further contributing to soil enrichment (Wilson \& Thompson 2005). The increase in organic soil carbon from the decomposition of leaf and branch litter can contribute to the soil's water-holding and nutrient-binding capability, especially in sandy soils.

This review paper was researched by using search terms such as "mesquite", "algarroba", "Prosopis", and "Prosopis glandulosa" in the Web of Science and Direct Science databases to generate the articles reviewed. We decided to focus on the particular mesquite species found in Texas, $P$. glandulosa, which has thus far eluded effective and efficient brush management over several decades. Personal interviews were conducted with mesquite management experts to understand in depth the issues facing brush management of the Prosopis species. While taking a cross-sectional review of potential solutions for Prosopis brush management around the world, this paper emphasizes $P$. glandulosa bush management in southwest North America as a focal point.

\section{Control of mesquite as an invasive species}

Careful and consistent land management is required to remove established mesquite trees and to prevent their aggressive reinvasion. Land managers have studied mechanical, chemical, fire, and biological control agents to control mesquite's unwanted growth which currently covers nearly one-third of Texas' pasture lands. In Texas, a mature mesquite tree can translo- 
cate as much as $167 \mathrm{~L}$ of water per day. TSSWCB estimated that removing 7 ha (17 acres) of established mesquite trees is equivalent of saving more than 1.2 million $L$ of water per year (TSSWCB 2010).

A possible control mechanism for mesquite growth is to restrict groundwater availability in controlled areas. Empirical hydrological and vegetational data have been used to create a model for $P$. velutina to explore the capacity for translocation of ground water and the potential for damaging the development of riparian ecosystems. The model predicted that a stand of $P$. velutina with height greater than $12 \mathrm{~m}$ translocates groundwater from depths of approximately $6 \mathrm{~m}$ or less (Stromberg \& Wilkins 1993).

In addition, access to ground water enabled the proliferation of the P. pallida on the highlands of Hawaii (Dudley et al. 2014). P. pallida in this region received more rainfall and developed differently from the lowland $P$. pallida, which received less rainfall and had greater access to groundwater. Moreover, the lowland $P$. pallida showed increased uptake rates of carbon (C), nitrogen ( $\mathrm{N})$, and phosphorus $(P)$, which contributed to the access to groundwater. Indeed, higher $\mathrm{N}$ mass concentration in the soil as well as denser canopies, larger basal trunk area and larger leaf area were found in sites where $P$. pallida had access to groundwater. The use of various water sources was measured and confirmed by oxygen-stable isotope ratios. If access to groundwater is reduced by either humankind or natural methods linkage between groundwater and self-generated soil nutrients will be minimized (Dudley et al. 2014).

Seed pods of the mesquite tree were used extensively by early cattle ranchers to feed their livestock which contributed to the change in grassland ecology, especially in the Southern USA, Argentina, Australia and Africa (Archer et al. 1995). As cattle grazed down the grass, removing the principal vegetative competitor to the mesquite trees, the mesquite seedlings sprouting from piles of manure were able to rapidly encroach on the former grass lands. Once established, the extensive surface root systems of the mesquite trees acted as competitive growth inhibitors, preventing the grassland's regrowth after being over-grazed. Locations with high stockloadings, even in different countries, have the highest density of mesquite because of the cycle of (1) cattle overgrazing, clearing the grasslands (2) the hungry cattle eat the mesquite pods, the cattle's digestive system scarifies the seeds which are then excreted in a manure rich environment-perfect for sprouting, and (3) these newly sprouted mesquite seedlings further inhibit the regrowth of grass while encouraging further growth of the mesquite seedling. The density of mesquite trees can be huge, up to 10,000 small ( 1 to $2 \mathrm{~cm}$ diameter) stems ha ${ }^{-1}$ in a new land that has been in- vaded for less than 10 to 15 years (Patch \& Felker 1997). Poor land management practices with years of sporadic mesquite treatments (herbicides, mechanical removal and control fires) only damage the above soil portion of the mesquite trees. Once damaged, the original few-stemmed trees regrow and resprout as multi-stemmed thickets, thus worsening the mesquites' negative impacts (Ansley et al. 1997).

\section{Current control measures}

\section{Mechanical}

Mechanical removal of mesquite trees has an immediate positive impact on mesquite tree control. Land managers use a specially designed deep-grubbing blade on a bulldozer or a track-hoe to remove the tree and root crown 20 to $25 \mathrm{~cm}$ below the soil, which is particularly effective. Afterwards, the rough ground needs are addressed, the pasture is re-seeded and spot application of herbicide on the regrowth and new seedlings is applied (Lyon, personal communication). Ill-timed or halfhearted mechanical removal of the trees just the above ground portion routinely leads to increased sprouting and increased density of the tree. Moreover, cuts must be made below the crown to ensure no resprouting. Newly sprouted seedlings can be killed if they are mowed off below the cotyledons, located approximately 2.54 and $3.81 \mathrm{~cm}$ above the ground. Optimal timing of mowing is between early spring and late fall when seeds typically sprout (Ansley et al. 2006).

Another method of reduction tested include competitive inhibition from grass roots as means to control mesquite growth (Johnson et al. 2000, Polley et al. 2003). Light levels of either low light level (6.0 \pm $0.4 \% \mu \mathrm{mol}$ [photon] $\mathrm{m}^{-2} \mathrm{~s}^{-1}$ at the soil level and $8.3 \pm 1.9 \% \mu \mathrm{mol}$ [photon] $\mathrm{m}^{-2} \mathrm{~s}^{-1}$ above the canopy) or high light level $(18.9 \pm 0.8 \%$ $\mu \mathrm{mol}$ [photon] $\mathrm{m}^{-2} \mathrm{~s}^{-1}$ at the soil level and $15.0 \pm 1.1 \% \mu \mathrm{mol}$ [photon] $\mathrm{m}^{-2} \mathrm{~s}^{-1}$ above the canopy), grass root exclusion to $0.15 \mathrm{~m}$ depth with $0.15 \mathrm{~m}$ diameter, and a control were tested. Perennial grass, a $\mathrm{C}_{4}$, Bothriochloa ischaemum (L.) Keng, var. songarica (Rupr.), was used to impede the propagation of mesquite trees based on the hypothesis that the test grasses would more effectively compete for soil moisture. For the control, the soil moisture was reduced by about 3\% from the original range of soil moistures of $28.4 \%$ to $27.4 \%$ down to $25.3 \%$ to $23.9 \%$ without grass. This reduction in soil moisture was accomplished by the use of canopies over the soil plots. This depression in soil moisture did not reduce the sprouting of mesquite seedlings nor did it inhibit the establishment of mesquite growth, but it did retard the growth of developing mesquite trees.

The $\mathrm{CO}_{2}$ effects on soil moisture were explored by enclosing a grassland plot $20 \mathrm{~m}$ from the other testing sites present in the study. The enclosed plot was exposed to a constant and uniform gradient of $550 \mu \mathrm{mol}$ $\mathrm{mol}^{-1} \mathrm{CO}_{2}$ concentration in two parallel, tunnel-shaped chambers, running from a north to south axis based on a previous field study (Johnson et al. 2000). The competitive grasses only reduced the number of seedlings that emerged, but the grass roots were not sufficiently competitive in restricting soil moisture to prevent the growth of mesquite. Finally, increased $\mathrm{CO}_{2}$ atmospheric gas would only lead to further propagation of mesquite trees (Johnson et al. 2000). Moreover, the increased soil-water level allowed for further propagation of mesquite trees.

\section{Burning}

Controlled burning has been identified as probably the most cost-effective method of mesquite removal (Teague et al. 2001). Mature Prosopis glandulosa are fire-resistant, but the seedlings are more susceptible to damage by fire; therefore, properly timed fires can lead to a complete eradication of the mesquite seedlings in an area. A recent study demonstrated that timing and intensity of fires were important to control P. glandulosa (Ansley et al. 2015). Two plots of land were created with acid-scarified mesquite seeds planted in either mid-grass or tall-grass plots. The fields were then burned in either winter, when the seedlings were 10 or 22 months old, or late summer when they were about 17 months old. About $85 \%$ of the 17 -month-old seedlings were destroyed in the summer burning compared to only $35 \%$ of the 10 -month-old seedlings' being destroyed in the winter fires. Summer fires on land with low-grass cover were adequate to destroy mesquite seedlings. Therefore, the evidence suggested ranchers do not need to continue the current practice of deferred grazing to increase the grass biomass with the intent of building adequate burning foliage for winter fires.

\section{Herbicides}

Topical and/or root applications of herbicides are not able to achieve a $100 \%$ kill rate of mesquite trees, and, furthermore, moderate herbicide injury can lead to increased sprouting of the trees (Ansley et al. 2006). Herbicides have been heavily used to combat mesquite propagation; however, herbicides have proven ineffective as the complete solution to the mesquite problem (Bovey \& Whisenant 1991). Furthermore, lands treated in the 1970's and 1980's by two treatments: (1) top-kill herbicides, and (2) root-kill herbicides, and a control were analyzed for cost-efficiency in treating mesquite trees (Ansley et al. 2004). The cost of using Triclopyr (3,4,6-trichloro-2pyridinyloxyacetic acid, butoxyethyl ester), a top-kill herbicide alone, at an application rate of $0.56 \mathrm{~kg} \mathrm{ha}^{-1}$ was reported to cost be 37 US \$ ha ${ }^{-1}$, while the cost of using a mixture of $0.28 \mathrm{~kg} \mathrm{ha}^{-1}$ Clopyralid, a root-kill herbicide, (3,6-dichloro-2-pyridinecarboxylic acid, monoethanolamine salt) plus 0.28 
kg ha-1 Triclopyr was approximately $\$ 62 \mathrm{ha}^{-1}$. Effective root-killing treatments cost between 60 and 70 US $\$ \mathrm{ha}^{-1}$ and must be continued for as long as 20 years, and topkilling treatments at 30 US \$ to 40 US \$ ha need to be continued for more than 10 years to achieve cost-effective results (Teague et al. 2001). Only the root-killing herbicide regime gave an economic return, while top-killing herbicide treatment did not, analyzed on annual grass yields between 1998 and 2000. In addition, variation in increased grass yield from year to year made it difficult to determine which type of grass is better suited to compete or cooccupy land with mesquite. However, Buffalo grass (Buchloe dactyloides) was concluded to have the highest growth rate and to be the best competitor to mesquite regrowth (Ansley et al. 2004).

Alternative chemical treatments that allow treated mesquite lands to be used for multi-uses such as livestock production and wildlife habitat have been investigated (Ansley et al. 2006). Three different treatments by aerial spray: (1) untreated, (2) Clopyralid alone at $0.28 \mathrm{~kg} \mathrm{ha}^{-1}$ and (3) $1: 1$ mixture of Clopyralid + Triclopyr at 0.28 $+0.28 \mathrm{~kg} \mathrm{ha}^{-1}$ were applied on two separate plots that were $80 \mathrm{~km}$ apart. Each treatment was replicated four times. The highest root kill rate using Clopyralid and Triclopyr was $56.7 \%$ with a standard error of $5.8 \%$, further substantiating that herbicides alone are not a final solution. On the other hand, the data demonstrated that herbicides can be used to manage the brush in a savannah ecosystem which appeals to modern management goals in maintaining diversity and creating multiple use options of rangelands (Cairns \& Lackey 1992, Fulbright 1996). The authors attribute the variability to the difference in soil composition and vegetation surrounding the mesquite trees on the two separate plots.

\section{Biological control}

The use of biological control agents, such as plant eating insects, was suggested as a low-cost method to control the growth of mesquite (DeLoach 1984). Over 300 insect species have been identified in Argentina and Paraguay that feed on the 30 different Prosopis species. The 10 most effective insect species identified were seed-feeding bruchid beetles belonging to the genera Rhipibruchus, Scutobruchus, Pectinibruchus, and Acanthoscedlides. These insects feed on the developing seeds of the mesquite, thus limiting and controlling the spread of mesquite trees. Other insects including gelechiid leaf-tier from the Evippe and the Recurvaria-Aristotelia group were identified as insects that fed on the mesquite's foliage. However, non-native insects as biological control agents for mesquite have never been cleared for introduction in the USA.

Biological controls were used in other countries for various Prosopis spp. with mixed results (Van Klinken et al. 2003,
Hamilton et al. 2004, Shackleton et al. 2014). For example, Van Klinken et al. (2003) evaluated the potential effects of Evippe and Prosopidopsylla flava, biological control agents from Argentina, in a study performed in Australia. Evippe flourish in the Australian climate, but the researchers were unable to predict how the insects' defoliation efforts affected the developmental rates, survival or reduction of mesquite trees. Moreover, despite the Prosopidopsylla flava's coming from the same region in Argentina as the Evippe, Prosopidopsylla flava failed to achieve the population density to make a substantial impact on the mesquite trees (Van Klinken et al. 2003)

\section{Estimation tools}

Innovation with brush management allows for more precise control of growth of Prosopis spp. Researchers combined the National Agricultural Imagery Program (NAIP) and a moderate-resolution (30m) Landsat-5 Thematic Mapper (TM) imagery to create free-of-charge maps that can be used by land managers to increase cost-effective methods of monitoring and controlling mesquite growth (Collins et al. 2015). The maps help the land owner decide where efforts need to be allocated to best manage the land and focus resources on key-targeted areas. In addition, The Texas Extension Service also has a tool to help estimate the economic cost of mesquite tree removal through various methods (Texas A\&M Agrilife Extension 2016). This tool gives a rough estimate of the cost associated with mechanical or chemical removal of mesquite depending on the density of the mesquite trees and the location of the area to be cleared. For example, when land managers rent equipment for mechanical removal or contract chemical spraying companies, they can use the tool to: (1) estimate how many mesquite trees need to be removed to make their work economically impactful, and (2) where they should concentrate their efforts based on digital imaging of the coverage of mesquite trees on their property.

\section{Alternative applications of mesquite}

\section{Food}

There is a developing trend to find economically viable uses for harvested mesquite trees and seeds to put sustained pressure on the ecosystem that will limit and ultimately reduce the negative impact from these invasive trees (Shackleton et al. 2014). A review by Felker et al. (2013) investigated the genus Prosopis, describing potential food applications which are similar to the food applications of the carob tree (Ceratonia siliqua) cultivated in Spain. Spain is the largest exporter of carob (the fruit pod from Ceratonia siliqua) at 26,185 tons year $^{-1}$ (FAOSTAT 2016). Carob can be formed into a powder that is used as a chocolate substitute, a caffeine-free coffee sub- stitute, and a gum similar to gum arabic (Barak \& Mudgil 2014).

Most of the Prosopis pods are from wild sources that are picked by hand with little automation. The pods are screened and then ground and sieved until the correct particle size is obtained for various products (Felker, personal communications). Studies on human food products sourced from the $P$. glandulosa are limited because of the high labor cost associated with harvesting the pods and the lack of established markets. See examples of different Prosopis pods in Fig. 2.

While pods are a direct food from mesquite trees, an indirect food created by the mesquite trees is honey. Mesquite trees are a rich and popular source of nectar for honey bee production (DeLoach 1984). Mesquite honey, currently imported from Mexico into the USA, costs approximately $7.93 \mathrm{US} \mathrm{kg}^{-1}$ (AMS 2016). Mesquite honey can also be found in the USA, but USA mesquite honey is not tracked by the USDA's national honey report. In 2015, the economic value of honey produced in the USA was an estimated 327 million US \$ (NASS 2016). The USA market demand for honey may increase the economic value of mature mesquite trees used by bees to produce honey in the USA, thus improving rancher land management returns. Bee foraging was measured to understand flowering and pod production of the $P$. glandulosa var. glandulosa in relation to honeybee pollination. The increased number of pods from the tree had an association with increased number of visitation by bees regardless of the nectar production (Lee \& Felker 1992).

Most mesquite trees in Peru are used as a source of fuel to cook meats similarly to the use of mesquite in the USA for barbeques. However, unlike the USA, Peru does not view its species of mesquite as a noxious weed and is not seeking to eradicate it. The Peruvian Prosopis pallida has been investigated by the experiment station of the University of Piura (Peru) since 1984, seeking to develop value-added products from the tree's fruit pods in lieu of using the tree as fire wood. Products developed from the mesquite pods include glutenfree flour, caffeine-free coffee bean substitutes, and a syrup called algarrobina (Grados \& Cruz 1996). Algarrobina is similar in appearance to molasses and is found to have a high sugar content up to $50 \%$ of algarrobina and a fiber content up to $32 \%$ of algarrobina (Bravo et al. 1998). Peruvian products, including the flour and algarrobina, have received USDA certified organic status in the USA. However, the algarroba products (which includes those from both Ceratonia siliqua and Prosopis species) are still an emerging industry and are yet to gain a large foothold in the international market (FAOSTAT 2016).

A gluten-free flour made from the seeds of another heavily studied species, Prosopis alba, has a unique flavor and aroma (Ta- 
keoka et al. 2008). The mesquite flour was determined to contain 2,5-dimethyl-3-ethylpyrazine ( $4.8 \%$ of the total volatiles), which has a pleasant cocoa, chocolate, burnt almond and filbert-hazelnut aroma with a low odor of threshold of $0.4 \mathrm{ppb}$. In addition, (y)-octalactone (0.4\%) and (y)-nonalactone $(1.6 \%)$ lend a coconut aroma (Felker et al. 2013). The chemical and nutritional properties of different fractions of Prosopis alba pods and seeds has also been studied (Sciammaro et al. 2016). The whole seed contained $34 \%$ protein, while the whole pod flour contained $5.8 \%$ protein, and the pulp (pericarp) flour contained $3.5 \%$ protein. In addition, the whole pod flour was found to have $44 \%$ sucrose compared to $41 \%$ sucrose in pulp flour. Another highlight of the analysis was iron content was approximately $57 \mathrm{ppm}$ in pods and approximately $54 \mathrm{ppm}$ in pulp flour, which could supplement a person's diet to meet the recommended daily intake of iron. Soluble dietary fiber was reported on a dry weight base as approximately $25 \%$ for pod flour total dietary fiber ( $84 \%$ of it being insoluble dietary fiber), while pulp flour was reported as about 23\% total dietary fiber ( $95 \%$ of it being insoluble fiber). Because the flour is gluten-free, the flour could be used in bakery formulations for the large and growing gluten-free bakery goods market (Sciammaro et al. 2016).

In addition, the gum made from the Prosopis spp. is comparable in functionality to other gums such as gum arabic (LópezFranco \& Goycoolea 2006). Mesquite pod gum can be used as an emulsifying and stabilizing ingredient. The greatest difference between the Prosopis alba (mesquite) gum and the gum arabic (Acacia senegal) is the mesquite's higher protein content (Vasile et al. 2016). The researchers documented that the mesquite gum was able to better reduce interfacial tension compared to gum arabic measured by interfacial tension oil-in-water emulsion interfaces. In addition, the volume droplet size distribution for emulsions containing $2 \%$ of mesquite gum had monomodal distribution of 0.7 to $60 \mu \mathrm{m}$, while gum arabic has a much broader range of droplets, 0.7 to $200 \mu \mathrm{m}$, suggesting mesquite gum is a more consistent emulsifier than gum arabic. The mesquite gum's improved interfacial and emulsifying properties are attributed to the mesquite gum's higher protein content (Dickinson 2003, Randall et al. 1988, RománGuerrero et al. 2009).

\section{Lumber}

A publication of the Texas Forest Service (Rogers 1986) compared the properties of Prosopis glandulosa var. glandulosa to other woods. The mesquite lumber was superior to almost all of the other woods in every category except for bending strength (Tab. 1). The mesquite ranks the lowest in volumetric shrinkage, about one-fourth that of other woods. The low volumetric shrinkage in mesquite woods is desirable as long as

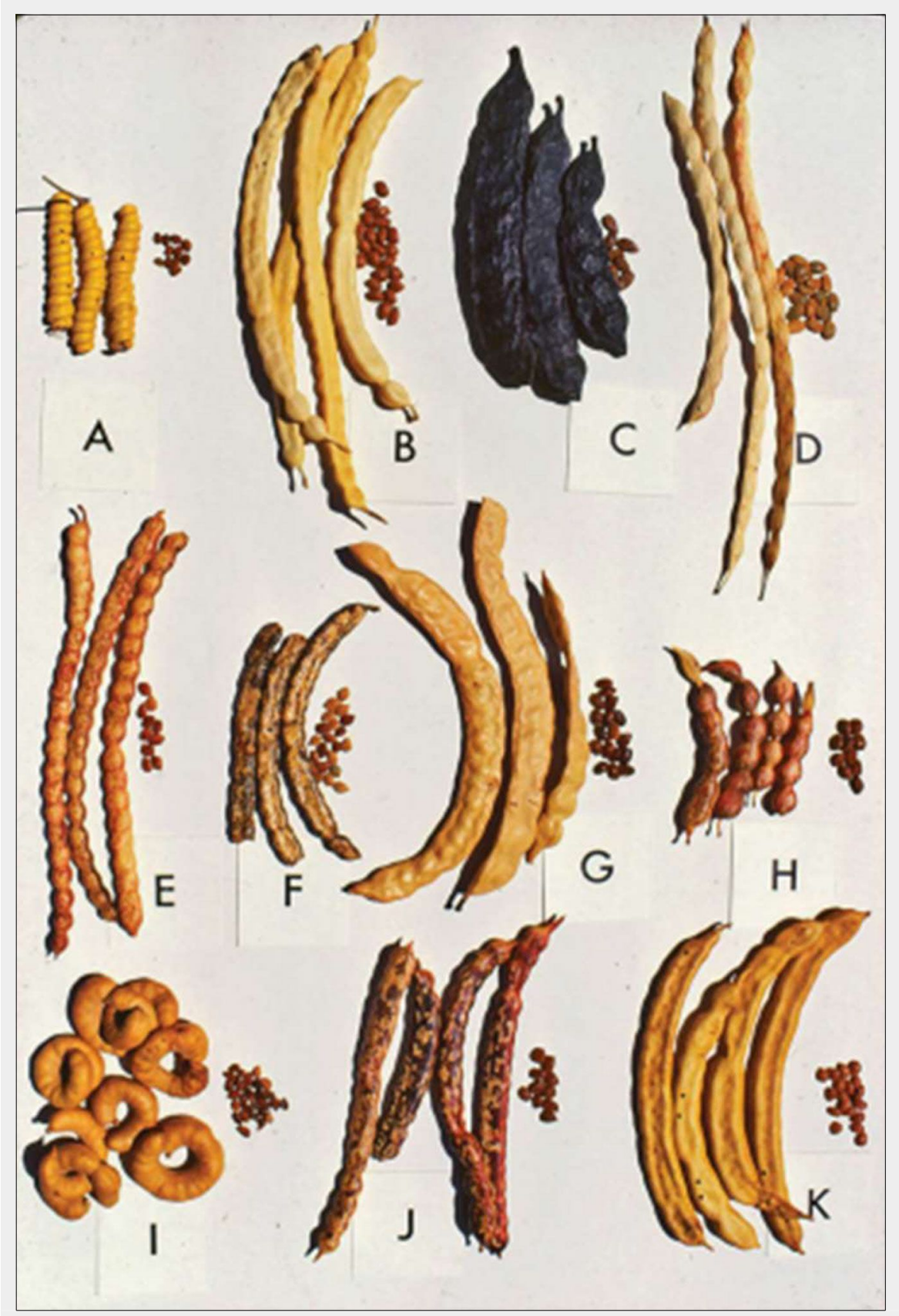

Fig. 2 - Prosopis pods of various species and origins. (A): screwbean from California, USA, P. pubescens; (B): mesquite from California, USA, P. glandulosa var. torreyana; (C): itin from Argentina, P. kuntzei; (D): mesquite from Baja California, Mexico, P. articulata; (E): algarrobo from Catamarca, Argentina, P. flexuosa; (F): algarrobo negro from Argentina, P. nigra; (G): algarrobo blanco from Santiago del Estero, Argentina, P. alba; (H): mesquite from New Mexico, USA, P. glandulosa var. glandulosa; (I): tamarugo from the Atacama Desert, Chile, $P$. tamarugo; $(J)$ : mesquite from south Texas, USA, $P$. glandulosa var. glandulosa; (K): mesquite from Senegal, Africa, P. juliflora (from Felker et al. 2013 - ๑ reprinted by permission of Taylor \& Francis Ltd).

the shrinkage remain uniform within the wood. In addition, its radial and tangential shrinkage are almost equal, which reduces stress on the wood during high moisture building, i.e., seasonal weather changes. No other wood compared during the test exhibited these same properties. However, one disadvantage explained by the author is mesquite wood can have a high variation in density, bending strength, volumetric shrinkage and radial shrinkage (Tab. 1 and
Tab. 2). The properties can have more than $300 \%$ variation in the volumetric trait of the wood, but overall, the volume shrinkage is still lower than any other wood (Rogers 1986). To maximize the trees used for lumber from $P$. glandulosa var. glandulosa, Felker et al. (1990) calculated 100 stems ha $^{-1}$ would generate the optimal base diameter of the mesquite tree in $35 \mathrm{~cm}$, to yield the most lumber. The calculated optimal spacing of $10 \times 10 \mathrm{~m}$ was later confirmed in a 
Tab. 1 - Selected physical and mechanical properties of mesquite (Prosopis glandulosa var. glandulosa) and various other fine woods (commonly used values - Rogers 1986). (1): Prosopis glandulosa var. glandulosa; (2): Quercus falcate Michx.; (3): Carya tomentosa Nutt.; (4): Carya illinoinensis (Wangenh.) K. Kock; (5): Pinus taeda L.; (6): Acer saccharum Marsh.; (7): Populus deltoides Bartr.; (*): MOE - modulus of elasticity; (**): Unitless.

\begin{tabular}{|c|c|c|c|c|c|c|c|}
\hline Property & Mesquite $^{1}$ & $\begin{array}{l}\text { Southern }^{2} \\
\text { Red Oak }\end{array}$ & $\begin{array}{c}\text { Mockernut }^{3} \\
\text { Hickory }\end{array}$ & Pecan $^{4}$ & $\begin{array}{l}\text { Loblolly }^{5} \\
\text { Pine }\end{array}$ & $\begin{array}{l}\text { Sugar } \\
\text { Maple }\end{array}$ & $\begin{array}{c}\text { Eastern } \\
\text { Cottonwoood }\end{array}$ \\
\hline Density $\left(\mathrm{kg} \mathrm{m}^{-3}\right)$ & 721 & 589 & 719 & 660 & 509 & 630 & 449 \\
\hline Bending Strength $\mathrm{MOE}^{*}$ ( $\mathrm{kPA}$ ) & 9515 & 10273 & 15306 & 11928 & 12342 & 12617 & 8963 \\
\hline Volumetric Shrinkage (\%) & 4.7 & 16.1 & 17.8 & 13.6 & 12.3 & 14.7 & 13.9 \\
\hline Radial/Tangential Shrinkage** & $2.2 / 2.6$ & $4.7 / 11.3$ & $7.7 / 11.0$ & $4.9 / 8.0$ & $4.8 / 7.4$ & $4.8 / 9.9$ & $3.9 / 9.2$ \\
\hline Side hardness (kg) & 1060 & 481 & 1089 & 826 & 313 & 658 & 195 \\
\hline
\end{tabular}

Tab. 2 - The variation in the physical and mechanical properties of mesquite wood (Prosopis glandulosa var. glandulosa) as tested by the Texas Forest Products Laboratory over a 15 -year period (Rogers 1986). (*): MOE, modulus of elasticity.

\begin{tabular}{lcccc}
\hline Property & Lowest & Highest & $\begin{array}{c}\text { Published } \\
\text { Average }\end{array}$ & $\begin{array}{c}\text { Average } \\
\text { Deviation (\%) }\end{array}$ \\
\hline Density $\left(\mathrm{kg} \mathrm{m}^{-3}\right)$ & 639 & 987 & 721 & 54.4 \\
Bending Strength MOE* (kPA) & 4220 & 9935 & 9515 & 136 \\
Volumetric Shrinkage (\%) & 1.8 & 7.5 & 4.7 & 316.7 \\
Side hardness (kg) & 549 & 1365 & 1060 & 149 \\
\hline
\end{tabular}

follow up study (Patch \& Felker 1997). In addition, the optimal basal diameter growth of $1.2 \mathrm{~cm}^{-1} \mathrm{yr}^{-1}$ was obtained when disking and pruning treatments were applied to the mesquite tree grove over 9 years.

Hardwood sawn timber has historically garnered higher prices than pulpwood with an average of $20.40 \mathrm{US} \$$ ton $^{-1}$ (Adams et al. 2015). In the TimberMart South, second quarter report of 2016, mesquite pulpwood averaged around 10 US $\$$ ton $^{-1}$ and sawn timber averaged 25 US $\$$ ton $^{-1}$ (TimberMart-South 2016). Since mesquite is not harvested on a large commercial scale within the USA, reports will show mesquite wood mixed with other hardwoods. For example, the hardwood pricing publication Hardwood Review Global did not report a specific cost for mesquite, while reporting many others like cottonwood, cherry, hard maple, hickory, red oak, white oak, and walnut (Hardwood 2016).

Moreover, through efforts to understand the mesquite lumber market, communication from the College Station Cooperative Extension office reported that a St. Angelo, TX, company is harvesting mesquite grinding, pelletizing and shipping it overseas for pellet stoves. In addition, another land owner cut and sold the mesquite wood he grubbed from his land as firewood. His sales of firewood paid for most of his removal cost. He also stated that land owners must do yearly follow-up to maintain control of the mesquite regrowth (Lyon, personal communications).

\section{Biofuel}

Crop residues, forest residues, grasses, and woody species may be used as lignocellulosic biomass to produce second generation biofuels. Reduction of greenhouse gas relative to petroleum gasoline was reported to be $19-48 \%$, 40-62\%, 90-103\%, 77$97 \%$ and $101-155 \%$ from corn ethanol, sugarcane, corn stover, switch grass and Miscanthus spp. grass, respectively (Wang et al. 2012). Ansley et al. (2010) analyzed mesquite's potential use as a biofuel and found not only would harvesting mesquite be economically feasible and sustainable, it also would yield other ecosystem benefits, including increased grass and foliage production for livestock foraging. The approach to control mesquite through biofuel production could benefit both the rancher and the green energy producer.

Moreover, the economic and greenhouse gas impact of Prosopis glandulosa was assessed over the southern great plains (SGP) of the USA (Wang et al. 2014). Researchers wanted to look at new sources of biofuel that could replace grain-based biofuels. The assessment compared mesquite against other regional bioenergy feedstock in the SGP and demonstrated that mesquite was better than all other feed stocks in sequestering greenhouse gases, offsetting inefficiency, and increas-

Tab. 3 - A comparison of the sweet sorghum, switchgrass, and mesquite production systems (Wang et al. 2014).

\begin{tabular}{|c|c|c|c|c|}
\hline \multirow{2}{*}{ Item } & \multicolumn{2}{|c|}{ Sweet Sorghum } & \multirow{2}{*}{ Switchgrass } & \multirow{2}{*}{ Mesquite } \\
\hline & Irrigated & Dryland & & \\
\hline Total cost (ha ${ }^{-1}$ \$US) & 1745.47 & 748.83 & 519.68 & 121.41 \\
\hline Biomass $\left(\mathrm{Mg} \mathrm{ha}^{-1}\right)$ & 17.79 & 6.93 & 12 & 2.2 \\
\hline Energy content (GJ ha-1) & 410 & 166 & 189.6 & 43.34 \\
\hline Greenhouse gas emission & 1256 & 439.4 & 354.09 & 108.52 \\
\hline Greenhouse gas offset & 7455 & 2904 & 4050 & 1100 \\
\hline Net Greenhouse gas offset (without land use change effect) & 6199 & 2464.6 & 3695.91 & 991.48 \\
\hline Greenhouse offset of alternative crop & 3370 & 1500 & 1500 & - \\
\hline GHG offset (with land use change effect) & 4085 & 1404 & 2550 & 1100 \\
\hline Net GHG offset (with land use change effect) & 2829 & 964.6 & 2195.91 & 991.48 \\
\hline Cost/biomass (\$ US/Mg) & 98.115 & 108.056 & 43.307 & 55.186 \\
\hline Cost/energy (\$ US/GJ) & 4.257 & 4.511 & 2.741 & 2.801 \\
\hline Cost/NGO (\$ US/Carbon equivalent, without land use change effect) & 0.282 & 0.304 & 0.141 & 0.122 \\
\hline Cost/NGO (\$ US/Carbon equivalent, with land use effect) & 0.617 & 0.776 & 0.237 & 0.122 \\
\hline Green house gas efficiency (without land use change effect) & 5.936 & 6.609 & 11.438 & 10.136 \\
\hline Green house gas efficiency (with land use change effect) & 3.252 & 3.195 & 7.202 & 10.136 \\
\hline
\end{tabular}


ing greenhouse gas use efficiency when land use change is considered. At a total cost of about 121 US $\$ h^{-1}$, the mesquite was found to produce energy levels of $43.34 \mathrm{GJ} \mathrm{ha}^{-1}$ (Tab. 3). Regrowth of the mesquite trees occurs in about half the time to grow a tree from seed (Ansley et al. 2010). This leads to obvious problems for land management as evidenced by the continuing reinvasion of range land by mesquite trees; however, the mesquite tree's ability to regenerate quickly makes it an ideal candidate for biofuel as biomass material.

The biomass needs of Prosopis glandulosa for gasification amounts and processes have been quantified (Chen et al. 2012). A small-scale biomass energy conversion plant was created to use brush material such as mesquite or redberry juniper (Juniperus pinchotii) as fuel in a small-scale (10kW) batch-type, fixed-bed gasifier. The effects of equivalence ratio, particle size, moisture content on the temperature profile, gas composition, and higher heating value (HHV) of both mesquite and redberry juniper wood were analyzed. When $\mathrm{N}_{2}$ was removed, the HHV of the gas end product of the mesquite and redberry juniper wood was $26 \%$ and $27.5 \%$, respectively, with the equivalence ratio being 2.7. In a follow up study, they looked at the tar formation and yield from gasification of mesquite and juniper wood in an updraft gasifier. Mesquite wood energy yield was found to be up to $3.5 \mathrm{MJ} \mathrm{kg}^{-1}$ when the moisture of the wood was at an ideal $6 \%$. In a follow up study, the gas yield formation from the mesquite ranged from 0.51 to 0.31 per unit mesquite in the gasification process (Chen et al. 2015).

Similar biofuel research on mesquite has been conducted in Turkey. Syrian mesquite (P. farcta) was investigated in Turkey for bio-oil production via catalytic supercritical liquefaction (Aysu \& Durak 2016). P. farcta was used in a catalytic reaction using $\mathrm{ZnCl}_{2}$ and $\mathrm{NaOH}$. Acetone was held at $295{ }^{\circ} \mathrm{C}$, which achieved a liquid yield of $49.7 \%$, indicating that most of the biomass was recovered as bio-oil, with HHV between 20 and $34 \mathrm{MJ} \mathrm{kg}^{-1}$.

\section{Biofilters}

Mesquite wood chips have also been tested as an organic filter material (OFM). An OFM is an organic material that retains different pollutants that later biodegrades into to $\mathrm{CO}_{2}, \mathrm{H}_{2} \mathrm{O}$, and $\mathrm{N}_{2}$. An OFM can be used as a bio-filter over an organic bed system, serving as a decentralization technology alternative to conventional municipal wastewater treatment (Sosa-Hernandez et al. 2016). This research investigated mesquite wood chips as an organic filter material that met both Mexico's and USA's regulations for reuse in irrigation. The optimal hydraulic loading rate over 200 days of testing was $1.07 \mathrm{~m}^{3} \mathrm{~m}^{-2} \mathrm{~d}^{-1}$. This resulted in a removal efficiency of biochemical oxygen demand by $92 \%$; and a reduction of the chemical oxygen demand by $78 \%$. The total suspended solids were reduced by $95 \%$ and there was a four-log reduction of fecal coliforms. These reported variables contributed to a mesquite wood chip OFM's meeting the critical requirements of waste water treatment for reuse in irrigation set by the USA and Mexican governments. Thus, the novel use of mesquite wood as a bio-filter was deemed viable.

\section{Human challenges to control}

Discussed throughout this paper are different options available for the uses of mesquite. However, the viewpoint of the very small land owner who may rely upon mesquite for his/her livelihood should not be overlooked. Farmers in South Africa will serve as example to illustrate this point. Shackleton et al. (2015) investigated different stakeholder viewpoints in South Africa: farmers, urban-informal, urban-affluent, and communal areas. All considered the costs of Prosopis to be greater than the benefits. However, even when they understood the invasive nature of Prosopis, approximately $63 \%$ of farmers continued to use the Prosopis' pods as fodder for their livestock. Two other common uses of Prosopis were fuelwood and shade. Thus, these applications may continue to make livestock owners more dependent on Prosopis products and lead to their resistance to control. In addition, governments and NGOs may promote utilization as a means of mesquite control even though utilization of mesquite alone has been proven insufficient to contain the problem of mesquite's rapid growth. Both of these efforts may lead to ongoing invasions. When the intent is unambiguously to restore invaded areas to productivity, then alternate uses can be a way of offsetting the control costs. Furthermore, the economic cost to run an efficient land management program is a barrier: the estimated control cost for appropriate mesquite management (> 9.5 million US $\left.\$ \mathrm{yr}^{-1}\right)$ far surpasses the entire budget of the Public Work programs of South Africa (Wise et al. 2012).

\section{Conclusions}

The applications for mesquite trees and their products are nearly limitless, but how to manage mesquite tree's invasion of lands still eludes researchers and government agencies alike. Mesquite tress were once heralded as the salvation of arid land as result of the Prosopis species' ability to fix nitrogen, enriching the soil; however, governments latter realized the water demand of mesquite tree outweighed its benefits. The uses of mesquites trees included food for human or animal consumption, lumber, biofuel, and an emerging application as an organic bio-filter. Land managers have tried to control mesquite growth through mechanical, burning, herbicides and biological control methods. However, humans mixed relationships with mesquite uses from different economical functions in society compound the problem to effectively control mesquite afflicted lands. As discussed in this article, many years of research have been spent on unlocking the uses of mesquite trees. However, the growing problem of mesquite land management still provides a rich opportunity for continual research into new ways to utilize mesquite lumber and seed pods in an environmental and economical sustainable manner.

\section{Acknowledgements}

Dr. Peter Felker provided valuable insight from his past work when contacted for this paper. Funding from a USDA SBIR project is appreciated.

\section{References}

Adams JP, Lingbeck JM, Crandall PG, Martin EM, O’Bryan CA (2015). Sweetgum: a new look. iForest - Biogeosciences and Forestry 8: 719-727. doi: 10.3832/ifor1462-008

AMS (2016). National honey report. Agricultural Marketing Service, US Department of Agriculture, St. Louis, MO, USA, vol 38, no. 6, pp. 9. [online] URL: http://www.ams.usda.gov/mnre ports/fvmhoney.pdf

Ansley JR, Huddle RJ, Kramp JA (1997). Mesquite ecology. In: "Brush sculptors: Innovations for tailoring brushy rangelands to enhance wildlife habitat and recreational value". Texas Agricultural Experiment Station, Vernon, TX, USA, web site. [online] URL: http://texnat.tamu.edu/lib rary/symposia/brush-sculptors-innovations-fortailoring-brushy-rangelands-to-enhance-wildlif e-habitat-and-recreational-value/mesquite-ecol ogyl

Ansley JR, Wu BX, Kramp B (2001). Observation: long-term increases in mesquite canopy cover in a North Texas savanna. Journal of Range Management 54: 171-176. - doi: 10.2307/4003179 Ansley RJ, Pinchak WE, Teague WR, Kramp BA, Jones DL, Jacoby PW (2004). Long-term grass yields following chemical control of honey mesquite. Journal of Range Management 57: 49-57. - doi: 10.2307/4003954

Ansley RJ, Kramp BA, Jones DL (2006). Converting mesquite thickets to savanna through foliage modification with clopyralid. Journal of Range Management 56: 72-80. - doi: 10.2458/ azu_jrm_v56i1_ansley

Ansley RJ, Mirik M, Castellano MJ (2010). Structural biomass partitioning in regrowth and undisturbed mesquite (Prosopis glandulosa): implications for bioenergy uses. Global Change Biology Bioenergy 2: 26-36. - doi: 10.1111/j.17571707.2010.01036.x

Ansley JR, Kramp BA, Jones DL (2015). Honey mesquite (Prosopis glandulosa) seedling responses to seasonal timing of fire and fireline intensity. Rangeland Ecology and Management 68: 194-203. - doi: 10.1016/j.rama.2015.01.008

Archer S, Schimel DS, Holland EA (1995). Mechanisms of shrubland expansion: land use, climate or $\mathrm{CO}_{2}$ ? Climate Change 29: 91-99. - doi: 10.1007/BF01091640

Aysu T, Durak H (2016). Bio-oil production via catalytic supercritical liquefaction of Syrian mesquite (Prosopis farcta). Journal of Supercritical Fluids 109: 26-34. - doi: 10.1016/j.supflu.2015. 
11.002

Babiker A (2006). Mesquite (Prosopis spp.) in Sundan: history, distribtuion and control. In: "Problems posed by the introduction of Prosopis in selected countries". FAO, Rome, Italy, pp. 11-20.

Barak S, Mudgil D (2014). Locust bean gum: processing, properties and food applications - A review. International Journal of Biological Macromolecules 66: 74-80. - doi: 10.1016/j.ijbiomac.20 14.02.017

Boggie MA, Strong CR, Lusk D, Carleton SA, Gould WR, Howard RL, Nichols C, Falkowski M, Hagen C (2017). Impacts of mesquite distribution on seasonal space use of lesser prairiechickens. Rangeland Ecology and Management 70: 68-77. - doi: 10.1016/j.rama.2016.09.006

Bovey RW, Whisenant SG (1991). Control of honey mesquite with clopyralid, triclopyr, or clopyralid: triclopyr mixtures. Journal of Range Management 44: 52-55. - doi: 10.2307/4002638 Bravo L, Grados N, Saura-Calixto F (1998). Characterization of syrups and dietary fiber obtained from mesquite pods (Prosopis pallida L.) Journal of Agricultural and Food Chemistry 46: 1727-1733. - doi: 10.1021/jf970867p

Burkart A (1976). A monograph of the genus Prosopis (Leguminosae subfam. Mimosoideae). Journal of the Arnold Arboretum 57: 219-249. [online] URL: http://www.jstor.org/stable/4378 1999

Canadell J, Jackson RB, Ehleringer JB, Mooney HA, Sala OE, Schulze ED (1996). Maximum rooting depth of vegetation types at the global scale. Oecologia 108: 583-595. - doi: 10.1007/BF 00329030

Cairns MA, Lackey RT (1992). Biodiversity and management of natural resources: the issues. Fisheries 17: 6-10. - doi: 10.1577/1548-8466(1992) 017<0006:BAMONR>2.0.CO:2

Chen W, Annamalai K, Ansley RJ, Mirik M (2012). Updraft fixed bed gasification of mesquite and juniper wood samples. Energy 41: 454-461. - doi: 10.1016/j.energy.2012.02.052

Chen W, Thanapal SS, Annamalai K, Ansley RJ (2015). Liquid yield from juniper and mesquite bio-fuel gasification. International Journal of Energy Research 39: 621-633. - doi: 10.1002/ er.3266

Collins CDH, Kautz MA, Tiller R, Lohani S, PonceCampos G, Hottenstein J, Metz LJ (2015). Development of an integrated multiplatform approach for assessing brush management conservation efforts in semiarid rangelands. Journal of Applied Remote Sensing 9 (1): 96057. doi: 10.1117/1.JRS.9.096057

DeLoach C (1984). Conflicts of interest over beneficial and undesirable aspects of mesquite (Prosopis spp.) in the United States as related to biological control. In: Proceedings of the " 6 th International Symposium on Biological Control". Vancouver (BC, Canada) 19-25 Aug 1984. Canadian Government Publ. Centre, Ottawa, Canada, pp. 301-340.

Dickinson E (2003). Hydrocolloids at interfaces and the influence on the properties of dispersed systems. Food Hydrocolloids 17: 25-39. doi: 10.1016/S0268-005X(01)00120-5

Dudley BD, Hughes RF, Ostertag R (2014). Groundwater availability mediates the ecosystem effects of an invasion of Prosopis pallida.
Ecological Applications 24: 1954-1971. 10.1890/13-1262.1

Ewens M, Gezan S, Felker P (2012). Five year field evaluation of Prosopis alba clones on $\mathrm{pH}$ 9-10 soils in Argentina selected for growth in the greenhouse at seawater salinities ( $45 \mathrm{dS} \mathrm{m}^{-1}$ ). Forests 3: 95-113. - doi: 10.3390/\$3010095

FAOSTAT (2016). Production quantities of carobs by country. FAO, Rome, Italy, web site. [online] URL: http://www.fao.org/faostat/en/\#data/QC/ visualize

Felker P, Meyer JM, Gronski SJ (1990). Application of self-thinning in mesquite (Prosopis glandulosa var. glandulosa) to range management and lumber production. Forest Ecology and Management 31: 225-232. - doi: 10.1016/03781127(90)90070-R

Felker P, Takeoka G, Dao L (2013). Pod mesocarp flour of North and South American species of leguminous tree Prosopis (mesquite): composition and food applications. Food Reviews International 29: 49-66. - doi: 10.1080/87559129.20 12.692139

FSIS-USDA (2016). Summary of recall cases in Calendar Year 2015. Web site. [online] URL: http://www.fsis.usda.gov/wps/portal/fsis/topics /recalls-and-public-health-alerts/recall-summa ries/recall-summaries-2015

Fulbright TE (1996). Viewpoint: a theoretical basis for planning woody plant control to maintain species diversity. Journal of Range Management 49: 554-559. - doi: 10.2307/4002299

Geesing D, Felker P, Bingham RL (2000). Influence of mesquite (Prosopis glandulosa) on soil nitrogen and carbon development: implications for global carbon sequestration. Journal of Arid Environment 46: 157-180. - doi: 10.1006/jare.200 0.0661

Grados N, Cruz G (1996). New approaches to industrialization of algarrobo (Prosopis pallida) pods in Peru. In: Proceedings of the Workshop "Prosopis Semiarid Fuelwood and Forage Tree Building Consensus for the Disenfranchised" (Falker P, Moss J eds). Washington (DC, USA) 13-15 Mar 1996. US National Academy of Sciences, Washington, DC, USA, pp. 3.25-3.42. [online] URL: http://www.researchgate.net/publi cation/280206836

Hamilton WT, McGinty A, Ueckert DN, Hanselka CW, Lee MR (2004). Brush management: past, present, future ( $1^{\text {st }}$ edn). Texas A\&M University Press, College Station, TX, USA, pp. 297. [online] URL: http://books.google.com/books?id= IgV24IYw4SIC

Hardwood (2016). Hardwood review global. Hardwood Publishing Inc., Charlotte, NC, USA, web site. [online] URL: http://www.hardwood review.com

Jackson RB, Canadell J, Ehleringer JR, Mooney HA, Sala OE, Schulze ED, Mooney HA (1996). A global analysis of root distributions for terrestrial biomes. Oecologia 108 (3): 389-411. - doi: 10.1007/BF00333714

Johnson HB, Polley HW, Whitis RP (2000). Elongated chambers for field studies across atmospheric $\mathrm{CO}_{2}$ gradients. Functional Ecology 14: 388-396. - doi: 10.1046/j.1365-2435.2000.0043 $5 . x$

Lee SG, Felker P (1992). Influence of water/heat stress on flowering and fruiting of mesquite (Prosopis glandulosa var. glandulosa). Journal of
Arid Environments 23: 309-319.

López-Franco YL, Goycoolea FM (2006). Goma de mezquite: una alternativa de uso industrial [Mesquite gum: an alternative industrial use]. Interciencia 31: 183-189. [in Spanish]

López Villagra GM, Felker P (1997). Influence of understory removal, thinning and $P$ fertilization on $\mathrm{N}_{2}$ fixation in a mature mesquite (Prosopis glandulosa var. glandulosa) stand. Journal of Arid Environment 36: 591-610. - doi: 10.1006/ jare.1996.0219

NASS (2016). Honey bee surveys and reports. National Agricultural Statistics Service, US Department of Agriculture, web site. [online] URL: http://www.nass.usda.gov/Surveys/Guide to_NASS_Surveys/Bee_and_Honey/

Patch NL, Felker P (1997). Silvicultural treatments for sapling mesquite (Prosopis glandulosa var. glandulosa) to optimize timber production and minimize seedling encroachment. Forest Ecology and Management 96: 231-240. - doi: 10.1016/S0378-1127(97)00041-8

Polley HW, Johnson HB, Tischler CR (2003). Woody invasion of grasslands: evidence that $\mathrm{CO}_{2}$ enrichment indirectly promotes establishment of Prosopis glandulosa. Plant Ecology 164: 85-94. - doi: 10.1023/A:1021271226866

Randall RC, Phillips GO, Williams PA (1988). The role of the proteinaceous component on the emulsifying properties of gum arabic. Food Hydrocolloids 2: 131-140. - doi: 10.1016/S0268-005X (88)80011-0

Rogers KE (1986). The wood properites of Mesquite (Prosopis glandulosa var. glandulosa): its basic properties and variability. Texas Forest Service, College Station, Texas, USA, vol. 40.

Rogers KE (2000). The magnificent mesquite $\left(1^{\text {st }}\right.$ edn). University of Texas Press, Austin, TX, USA, pp. 167. [online] URL: http://books. google.com/books?id=usBfOqtoR8EC

Román-Guerrero A, Orozco-Villafuerte J, PérezOrozco JP, Cruz-Sosa F, Jiménez-Alvarado R, Vernon-Carter EJ (2009). Application and evaluation of mesquite gum and its fractions as interfacial film formers and emulsifiers of orange peel-oil. Food Hydrocolloids 23: 708-713. - doi: 10.1016/j.foodhyd.2008.06.005

Sciammaro L, Ferrero C, Puppo MC (2016). Chemical and nutritional properties of different fractions of Prosopis alba pods and seeds. Journal of Food Measurement and Characterization 10: 103-112. - doi: 10.1007/s11694-015-9282-z

Shackleton RT, Le Maitre DC, Pasiecznik NM, Richardson DM (2014). Prosopis: a global assessment of the biogeography, benefits, impacts and management of one of the world's worst woody invasive plant taxa. AoB Plants 6: 1-18. - doi: 10.1093/aobpla/plu027

Shackleton RT, Le Maitre DC, Richarson DM (2015). Stake holder perceptions and practices Prosopis (mesquite) invasions and management in South Africa. Ambio 44 (6): 569-581. doi: 10.1007/s13280-014-0597-5

Soper FM, Boutton TW, Sparks JP (2015). Investigating patterns of symbiotic nitrogen fixation during vegetation change from grassland to woodland using fine scale $\delta(15) \mathrm{N}$ measurements. Plant, Cell and Environment 38: 89-100. doi: 10.1111/pce.12373

Sosa-Hernandez DB, Vigueras-Cortes JM, Garzon-Zuniga MA (2016). Mesquite wood chips 
(Prosopis) as filter media in a biofilter system for municipal waste water treatment. Water Science and Technology 73: 1454-1462. - doi: 10.2166/wst.2015.595

Stromberg JC, Wilkins SD (1993). Vegetation-Hydrology Models: Implications for management of Prosopis velutina (velvet mesquite) riparian ecosystems. Ecological Applications 3 (2): 307314. - doi: 10.2307/1941833

Takeoka G, Felker P, Prokopiuk D, Dao L (2008). Volatile constituents of mesquite (Prosopis) pods. In: "Food Flavor: Chemistry, Sensory Evaluation, and Biological Activity" (Tamura $\mathrm{H}$, Ebeler SE, Kubota K, Takeoka GR eds). American Chemical Society, Washington, DC, vol. 988, pp. 98-108. - doi: 10.1021/bk-2008-0988. choog

Teague WR, Ansley RJ, Kreuter UP, Pinchack WE, McGrann JM (2001). Economics of managing mesquite in north Texas: a sensitivity analysis. Journal of Range Management 54 (5): 553-560. - doi: $10.2307 / 4003584$

Texas A\&M Agrilife Extension (2016). How to estimate cost for controlling mesquite. Texas A\&M Agrilife Extension, College Station, TX, USA, web site. [online] URL: http://texnat. tamu.edu/about/brush-busters/mesquite/how- to-estimate-cost-for-controlling-mesquite/ TimberMart-South (2016). South-wide averages price. Center for Forest Business, Warnell School of Forestry and Natural Resources, University of Georgia, Atlanta, GE, USA, web site. [online] URL: http://www.timbermart-south. com/prices.html

TSSWCB (2010). Agency reports. Texas State Soil and Water Conservation Board 1-8, Temple, TX, USA, web site. [online] URL: http://www. tsswcb.texas.gov/about/agency-reports Van Klinken RD, Fichera G, Cordo H (2003). Targeting biological control across diverse landscapes: the release, establishment, and early success of two insects on mesquite (Prosopis spp.) insects in Australian rangelands. Biology Control 26: 8-20. - doi: 10.1016/S1049-9644(02) 00107-X

Vasile FE, Martinez MJ, Pizones Ruiz-Henestrosa VM, Judis MA, Mazzobre MF (2016). Physicochemical, interfacial and emulsifying properties of a non-conventional exudate gum (Prosopis alba) in comparison with gum arabic. Food Hydrocolloids 56: 245-253. - doi: 10.1016/j.foodhyd. 2015.12.016

Velarde M, Felker P, Degano C (2003). Evaluation of argentine and peruvian Prosopis germplasm for growth at seawater salinities. Journal Arid Environment 55: 515-531. - doi: 10.1016/S01401963(02)00280-X

Wang M, Han J, Dunn JB, Cai H, Elgowainy A (2012). Well-to-wheels energy use and greenhouse gas emissions of ethanol from corn, sugarcane and cellulosic biomass for US use. Environment Research Letters 7: 45905. - doi: 10.1088/1748-9326/7/4/045905

Wang T, Park S, Ansley RJ, Amosson SH (2014). Economic and greenhouse gas efficiency of honey mesquite relative to other energy feedstocks for bioenergy uses in the Southern Great Plains. Bioenergy Research 7: 1493-1505. doi: 10.1007/s12155-014-9475-z

Wilson TB, Thompson TL (2005). Soil nutrient distributions of mesquite-dominated desert grasslands: changes in time and space. Geoderma 126: 301-315. - doi: 10.1016/j.geoderma.20 04.10 .002

Wise RM, Van Wilgen BW, Le Maitre DC (2012). Costs, benefits and management options for an invasive alien tree species: the case of mesquite in the Northern Cape, South Africa. Journal of Arid Environment 84: 80-90. - doi: 10.1016/j.jaridenv.2012.03.001 